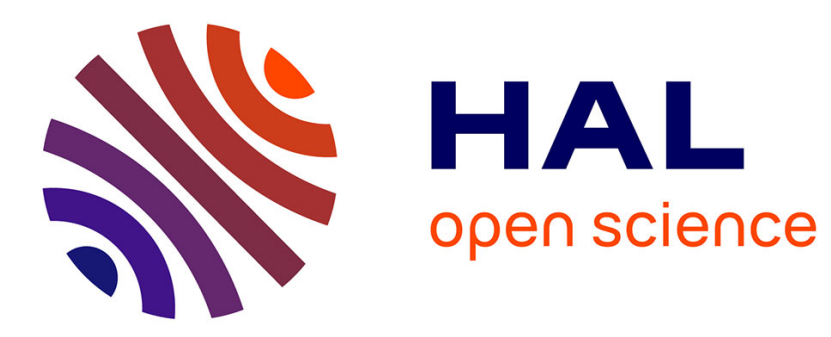

\title{
Groundwater promotes emergence of asporogenic mutants of emetic Bacillus cereus
}

Ludivine Rousset, Béatrice Alpha-Bazin, Alice Chateau, J. Armengaud, Thierry Clavel, Odile Berge, Catherine Duport

\section{To cite this version:}

Ludivine Rousset, Béatrice Alpha-Bazin, Alice Chateau, J. Armengaud, Thierry Clavel, et al.. Groundwater promotes emergence of asporogenic mutants of emetic Bacillus cereus. Environmental Microbiology, 2020, 22, pp.5248-5264. 10.1111/1462-2920.15203 . hal-02921272

\section{HAL Id: hal-02921272 \\ https://hal.inrae.fr/hal-02921272}

Submitted on 10 Jun 2021

HAL is a multi-disciplinary open access archive for the deposit and dissemination of scientific research documents, whether they are published or not. The documents may come from teaching and research institutions in France or abroad, or from public or private research centers.
L'archive ouverte pluridisciplinaire HAL, est destinée au dépôt et à la diffusion de documents scientifiques de niveau recherche, publiés ou non, émanant des établissements d'enseignement et de recherche français ou étrangers, des laboratoires publics ou privés.

\section{()ㅜ) $\Theta$}

Distributed under a Creative Commons Attribution - NoDerivatives| 4.0 International 


\section{Groundwater promotes emergence of asporogenic mutants of emetic}

\section{Bacillus cereus}

Ludivine Rousset $^{1,3}$, Béatrice Alpha-Bazin² ${ }^{2}$ Alice Chateau ${ }^{1}$, Jean Armengaud ${ }^{2}$, Thierry

Clavel $^{1}$, Odile Berge ${ }^{3}$ and Catherine Duport*1

${ }^{1}$ Avignon Université, INRAE, UMR SQPOV, F-84914, Avignon, France

${ }^{2}$ Université Paris Saclay, CEA, INRAE, Département Médicaments et Technologies pour la Santé (DMTS), SPI, 30200 Bagnols-sur-Cèze, France.

${ }^{3}$ INRAE, Pathologie Végétale, F-84140, Montfavet, France.

*Corresponding author: Pr. Catherine Duport

Address: Avignon Université, INRAE, UMR SQPOV, F-84914, Avignon, France.

E-mail: catherine.duport@univ-avignon.fr.

Phone: +33 432722507

Running tittle: B. cereus survival in groundwater

This article has been accepted for publication and undergone full peer review but has not been through the copyediting, typesetting, pagination and proofreading process which may lead to differences between this version and the Version of Record. Please cite this article as doi: $10.1111 / 1462-2920.15203$ 


\section{Originality-Significance Statement}

This work reports for the first time that asporogenic mutants of Bacillus cereus accumulate in a natural oligotrophic medium. As groundwater is used to irrigate food crops, and B. cereus is a food-borne pathogen, these findings are highly significant for human health.

\section{Summary}

Bacillus cereus is a ubiquitous endospore-forming bacterium, which mainly affects humans as a food-borne pathogen. B. cereus can contaminate groundwater used to irrigate food crops. Here, we examined the ability of the emetic strain B. cereus F4810/72 to survive abiotic conditions encountered in groundwater. Our results showed that vegetative $B$. cereus cells rapidly evolved in a mixed population composed of endospores and asporogenic variants bearing spo0A mutations. One asporogenic variant, VAR-F48, was isolated and characterized. VAR-F48 can survive in sterilized groundwater over a long period in a vegetative form, and has a competitive advantage compared to its parental strain. Proteomics analysis allowed us to quantify changes to cellular and exoproteins after 24 and $72 \mathrm{~h}$ incubation in groundwater, for VAR-F48 compared to its parental strain. The results revealed a significant rerouting of the metabolism in the absence of Spo0A. We concluded that VAR-F48 maximizes its energy use to deal with oligotrophy, and the emergence of spo0A-mutated variants may contribute to the persistence of emetic B. cereus in natural oligotrophic environments. 


\section{Introduction}

Groundwater accounts for most of the liquid fresh water on earth. It is the greatest water resource for humans and is increasingly used to irrigate food crops and to wash vegetables (Siebert et al., 2010). Water from underground aquifers is often considered to be of better microbiological quality than surface water, as it has undergone natural filtration as it percolated through the overlying layers of soil (John and Rose, 2005; Dillon et al., 2008). However, food borne pathogens such as Bacillus cereus have been isolated from groundwater in viable and cultivable forms (Brillard et al., 2015).

B. cereus is a soil-borne, endospore-forming, Gram-positive bacterium. It is transported from soil into the groundwater by leaching (Brillard et al., 2015). Leaching is increased by heavy rainfall and intensive irrigation, both of which will increase with global warming (Zhou et al., 2010; Green and Anapalli, 2018; Saleem et al., 2020). In addition to increasing the flow of water through the soil, global warming may affect the diversity of bacteria (Classen et al., 2015). In the case of B. cereus, it could contribute to increase the population of pathogenic mesophilic strains in the soil (Carlin et al., 2010), and consequently in groundwater. It raises the question of the health risks associated with groundwater contamination. The health risks depend on the size of the inoculum, but also on the ability of B. cereus to survive the hostile abiotic conditions encountered in groundwater. These conditions include a relatively low temperature $\left(16^{\circ} \mathrm{C}\right)$ and low levels of available organic matter (Rousset et al., 2019). B. cereus is a facultative anaerobic chemoorganotroph, capable of both respiratory and fermentative metabolism (Rosenfeld et al., 2005; Duport et al., 2006), and not an oligotroph per se, i.e., capable of growing under conditions of extreme energy or/and nutrient limitation 
(Lever et al., 2015). However, it has a considerable capacity for metabolic adaptation, allowing it to survive and grow under various stress conditions, affording it a considerable pathogenic potential (Duport et al., 2016).

B. cereus causes food-borne diseases primarily characterized by emetic or diarrheal syndromes. Diarrheal syndromes are thought to be caused by ingestion of B. cereus cells and / or spores, which can then produce Hemolysin BL (HBL), Non-hemolytic enterotoxin (Nhe) and/or Cytotoxin K (CytK) in the intestine (Stenfors Arnesen et al., 2008; Jessberger et al., 2015). However, B. cereus also produces several other proteins with toxic effects in vitro or in animal models, and some of them may also contribute to symptoms in these syndromes (Ramarao and Sanchis, 2013). Emetic syndromes, in contrast, are caused directly by the ingestion of a toxin, cereulide, produced by B. cereus as it grows in food (Agata et al., 2002).

B. cereus is part of a group of closely related species and lineages, including Bacillus anthracis, Bacillus cytotoxicus, Bacillus mycoides, Bacillus pseudomycoides, Bacillus thuringiensis, Bacillus toyonensis, and Bacillus weihenstephanensis, which in the literature is often referred to as Bacillus cereus sensu lato (Drobniewski, 1993; Guinebretiere et al., 2013; Pfrunder et al., 2016; Liu et al., 2017; Ehling-Schulz et al., 2019; Carroll et al., 2020). Previous studies have divided B. cereus s.l. into seven major phylogenetic groups (Guinebretiere et al., 2008; Guinebretiere et al., 2010), several of which contain strains known colloquially as “ $B$. cereus”. The seven genetic groups have different thermal adaptive capacities, and varying degrees of association with health risks (Guinebretiere et al., 2008; Carroll et al., 2019; EhlingSchulz et al., 2019). Group III is often regarded as a high-health risk group, as it contains $B$. 
cereus s.l. strains capable of causing anthrax or emetic illness (Guinebretiere et al., 2008; Kolsto et al., 2009; Guinebretiere et al., 2010).

In this study, we investigated the ability of the emetic reference $B$. cereus strain F4810/72 (also named AH187) to survive long-term under extreme nutrient and energy deprivation, mirroring the abiotic conditions encountered in natural groundwater. Incubating vegetative $B$. cereus F4810/72 cells in groundwater at $16{ }^{\circ} \mathrm{C}$ resulted in selection of asporogenic spo0A mutants. Relative quantitative proteomics analyses were used to compare the protein profile of the parental strain and a spo0A-mutated variant. Results indicated that emerging mutants expressed the Growth Advantage in Stationary Phase (GASP) phenotype.

\section{Results}

Survival of B. cereus F4810/72 in groundwater generates a mixed population with normal and atypical colony morphologies

B. cereus survival was studied in sterilized groundwater under physicochemical conditions designed to mimic natural conditions $\left(16^{\circ} \mathrm{C}\right.$ under agitation; (Rousset et al., 2019)). Figure $1 \mathrm{~A}$ shows a biphasic decay profile of viable cells over 30 days. Accordingly, data were best fit by the biphasic model using the GInaFiT freeware modeling tool (Geeraerd et al., 2005). The specific rate of decay is $1.47 \pm 0.65$ day $^{-1}$ in the first fast phase and is related to $91 \pm 5 \%$ of the initial population, while the specific decay rate is $0.04 \pm 0.02$ day $^{-1}$ in the second slow phase (Fig. 2). After 3 days' incubation, which corresponds to the end of the first decay phase, almost all viable cells (4.2 $\pm 0.6 \log \mathrm{CFU})$ were recovered as heat-resistant endospores $(4.3 \pm 0.8 \log$ CFU), whereas after 30 days, only $16.8 \pm 4.5 \%$ of the viable cells were recovered as heat- 
resistant endospores. Spores therefore germinated in groundwater (Brillard et al., 2015). Heattreated culture samples formed uniform colonies on LB agar plates (data not shown). However, colony heterogeneity, with colonies differing in size and appearance, was observed with untreated samples after 6 days' incubation in groundwater (Fig. 1B). The differences in appearance between atypical and standard colonies were further enhanced by the addition of Congo Red (Fig. 1C), suggesting that the B. cereus population contained both WT and variant bacteria (Worsham and Sowers, 1999). Fig. 1A shows that morphological variants quickly accumulated over 8 days and constituted the main population after 30 days (91.8 $\pm 6.0 \%$ ), replacing heat-resistant endospores. Accumulation of variants was not due to contamination of the stock strain (data not shown). Taken together, these data suggest that spore germination can promote the emergence of variants in groundwater. However, we cannot exclude the possibility that very few vegetative cells mutated and became non-sporulating cells.

To determine whether the enrichment of morphological variants was a result of nutrient deficiency, we compared the dynamics of $B$. cereus populations grown in groundwater and MOD50 medium (Rosenfeld et al., 2005). Variants accumulated 20 days earlier in oligotrophic groundwater than in minimal MOD50 medium (data not shown), suggesting that extreme nutrient deficiency accelerates the emergence of morphological B. cereus variants.

\section{Genetic analysis of morphological variants}

To determine whether these morphological variants shared characteristics, we isolated 12 distinct variants from four independent experiments. Morphological differences were maintained for all of them and were stable following subculture in LB (data not shown). We 
then tested the capacity of bacteria to form heat-resistant endospores in Fortified Nutrient Agar (FNA (Gonzalez et al., 1995)). The proportion of heat-resistant colonies obtained after 5 days' incubation was $0.1 \pm 0.2 \%$, indicating that morphological variants are asporogenic bacteria. Since the variant phenotype was irreversible, it could result from loss of endogenous plasmids or gene mutations, especially in the gene encoding the sporulation response regulator Spo0A that mutates predominantly in B. anthracis (Sastalla and Leppla, 2012).

To test the first hypothesis, PCR assays amplifying each of the four endogenous plasmids present in F4810/72 were performed. PCR products for WT and variant strains were identical, indicating that variants had conserved all four plasmids (data not shown).

We next tested the gene mutation hypothesis by amplifying and sequencing the spo0A gene. Strikingly, all of the selected variants contained a mutation in spo0A, with a different mutant subpopulation in each experiment (data summarized in Fig. S1). Closer analysis of spo0A sequences revealed the following four genetic variations (Fig. S1): (1) insertion of GA at position 700 of the spoOA ORF, resulting in truncation of 11 amino acids in Spo0A; (2) a nonsynonymous $(C \rightarrow T)$ mutation at position 563 resulting in an Ala $\rightarrow$ Val alteration; (3) a nonsynonymous $(\mathrm{C} \rightarrow \mathrm{T})$ mutation at position 667 changing $\operatorname{Arg} \rightarrow \mathrm{Cys}$; (4) a synonymous $(\mathrm{G} \rightarrow \mathrm{A})$ mutation at position 39.

The first three variations could clearly alter the primary structure of the Spo0A protein and thus, may cause a sporulation deficiency in variants. A synonymous mutation, on principle, does not alter the protein's structure, but it may alter the structure and function of the mRNA (LebeufTaylor et al., 2019). To determine whether the synonymous mutation detected in the VAR-F48 subpopulation variant is the genetic determinant of the sporulation deficiency observed, its 
whole genome was sequenced. This analysis revealed two additional non-synonymous mutations, at positions 3797954 and 2222681 (nucleotide locations are in reference to the $B$. cereus AH187 genome sequence, NCBI RefSeq Accession NC_011658.1). These mutations respectively altered codon 178 of $c t a A$ (GCT $\rightarrow$ ACT, Ala $\rightarrow$ Thr), encoding heme A synthase, and codon 49 of the BCAH187_A2382 gene (CAC $\rightarrow$ CAG, His $\rightarrow$ Asp), encoding a protein of unknown function (Fig. S1). Thus, the asporogenic phenotype of VAR-F48 cannot be linked solely to the nonsynonymous mutation identified in spo0A.

Survival of the asporogenic VAR-F48 strain in groundwater

Genetic variants are generally adapted to the environment where they evolved, so to determine whether VAR-F48 has a distinct advantage over the WT strain in groundwater, we examined its survival alongside that of the WT parental strain. The survival kinetics of the two strains were compared using the biphasic model (Fig. 2). The data show that the specific rate of decay of VAR-F48 was lower in the first fast phase and higher in the second slow phase $(0.54 \pm 0.20$ day $^{-1}$ and $0.14 \pm 0.06$ day $^{-1}$, respectively) compared to WT. As a result, the reduction rate reached $3.5 \log$ in 30 days for VAR-F48 cells while it reached 1.5 log reduction for WT cells. Finally, although VAR-F48 can survive for 30 days in groundwater, its survival rate was lower than that of its parent.

Cellular proteome analysis provides clues to survival of asporogenic VAR-F48 in groundwater To further investigate the molecular mechanisms used by VAR-F48 to survive in groundwater, we compared the cellular proteomes of asporogenic VAR-F48 and endospore-forming WT after 
incubation in groundwater for $24 \mathrm{~h} \mathrm{(T1)} \mathrm{and} 72 \mathrm{~h}$ (T2) (Fig. S2). The inoculum (T0) was exponentially growing cells cultivated in MOD50 medium (Rosenfeld et al., 2005), which were harvested at maximal growth rate $\left(\mu_{\max }\right)$. Interestingly, the $\mu_{\max }$ for VAR-F48 $\left(0.15 \pm 0.05 \mathrm{~h}^{-1}\right)$ was higher than that for WT $\left(0.09 \pm 0.01 \mathrm{~h}^{-1}\right)$, indicating that VAR-F48 grows faster than WT in nutrient-replete medium.

Shotgun proteomics analysis was performed on three biological replicates for each strain at each of the three time-points. In total, 2184 cellular proteins were identified by at least two distinct peptides across all 18 samples analyzed (Table S1). Principal Component Analysis (PCA) was performed on normalized data. An adjusted $p$-value $<0.05$ and a $\mid$ fold-change $\geq 1.5$ were required in at least one pairwise comparison across the dataset (Fig. 3A). This analysis revealed good homogeneity of the replicates at each time-point, and clear segregation between VAR-F48 and WT samples. PCA also indicated that VAR-F48 samples collected after $24 \mathrm{~h}$ and $72 \mathrm{~h}$ converged, whereas WT samples segregated in a time-dependent manner. This observation indicates that proteome remodeling occurring in VAR-F48 differed from that occurring in the WT strain, and that this remodeling may be completed earlier in VAR-F48. All possible pairwise comparisons to identify proteins that were differentially accumulated (DAPs) between VAR-F48 and WT samples at the same time points were carried out to identify protein profiles specifically associated with VAR-F48 survival (Table S2). Overall, 296 DAPs were identified, how they overlap at the three time points is illustrated in Fig. 3B. Three main groups of differentially abundant proteins were distinguished: (1) those that are common to T0, T1 and T2; (2) those that are common to T1 and T2; and (3) those that are specific to each time-point. 
Group 1: this group includes 14 proteins that differentially accumulated in VAR-F48 compared to WT both in MOD50 medium (inoculum, T0) and in groundwater after $24 \mathrm{~h}$ (T1) and/or $72 \mathrm{~h}$ (T2) incubation. Therefore, the genetic background probably contributes to enrichment or depletion of these proteins in VAR-F48. Of these 14 proteins, four were more abundant in VAR-F48 compared to WT, and ten were produced at lower levels in VAR-F48 than in WT (Table 1).

Among the enhanced-DAP, we found a lactate dehydrogenase (LDH), which regenerates $\mathrm{NAD}^{+}$ from $\mathrm{NADH}$, with concomitant reduction of pyruvate to lactate to regulate overflow metabolism under aerobiosis; a flavohemoprotein (Hmp), which is known to protect bacteria from endogenous redox stress (Moore et al., 2004); and a component of the thiamine pyrophosphate biosynthesis pathway (ThiS). Thiamine pyrophosphate is an important co-factor for several enzymes involved in energy metabolism, and might be involved in the adaptation of bacteria to energy stress (Gigliobianco et al., 2010). Taken together, these proteins reflect changes to energy/redox metabolic mechanisms. Among the proteins that were less abundant in VAR-F48 than in WT, two (CesC and CesD) are essential for posttranslational control of cereulide synthesis (Lucking et al., 2015). In addition, EA1, which is known to self-assemble into a paracrystalline layer on the surface of bacilli, was undetectable in VAR-F48 at any of the three time points (Table 1). In B. anthracis, both EA1 and Sap can self-assemble (Kern et al., 2012). B. cereus AH187 synthesizes a protein (B7HXP4), which resembles Sap. Like EA1, B7HXP4 was identified as a decreased-DAP, and was not detected in VAR-F48. The final protein in this subgroup is Spo0A, which was also undetectable in VAR-F48 (Table 1). This result suggests that VAR-F48 does not synthetize Spo0A due to the spo0A mutation. To confirm 
this finding, we analyzed the proteome of VAR-F48 grown in LB medium; Spo0A, EA1, B7HPX4, and Ces proteins were also undetectable in these conditions (data not shown; confirmed by Western-blot, Fig. 6).

Group 2. This group consisted of 16 proteins that differentially accumulated persistently after $24 \mathrm{~h}$ incubation in groundwater. These proteins may thus be key components of the sustained molecular response to the stress conditions encountered in groundwater.

Of the 16 DAPs, thirteen were detected at higher abundance, and three at lower abundance in VAR-F48 compared to WT (Table 2). Of the 13 enhanced-DAPs, eight were assigned to central metabolic pathways, one was predicted to be a signal sensor, and one corresponded to Catabolite Control Protein A (СсрA). CсрA is a pleiotropic transcriptional regulator involved in the general mechanisms controlling carbon catabolite repression (Gorke and Stulke, 2008). The decreased-DAPs included sigma factor $\mathrm{E}\left(\sigma^{\mathrm{E}}\right)$, which drives sporulation in Bacilli (Fimlaid and Shen, 2015), and the sporulation-associated protein CotE. Taken together, these data indicate that VAR-F48 enters into an active survival process, which is distinct from the sporulation process.

Group 3. This group includes transient DAPs that could reflect the metabolic status of VARF48 in nutrient-replete inoculum (subgroup T0) and in nutrient-depleted groundwater after $24 \mathrm{~h}$ (subgroup T1) and $72 \mathrm{~h}$ incubation (subgroup T2).

Subgroup T0. Of the 157 DAPs identified only at T0, expression of 61 was enhanced and of 96 was decreased in VAR-F48 compared to WT, indicating a general down-regulation of protein expression in VAR-F48 compared to WT. We classified DAPs according to Clusters of Orthologous Groups (COG) groupings (Table S2), and Figure 4 (T0) shows the distribution of 
the 53 enhanced-DAPs and 71 decreased-DAPs that were functionally categorized. The data indicate that proteins related to lipid transport and metabolism, and to a lesser extent, amino acid or nucleotide transport and metabolism, were expressed at lower levels in VAR-F48. In contrast, proteins related to coenzyme transport, general metabolism, and defense mechanisms were expressed at higher levels in VAR-F48. Of the 12 decreased-DAPs in the lipid group, five were annotated as acetyl-CoA dehydrogenases, three were acetyl-CoA synthases, and two were enoyl-CoA hydratases. This profile suggests a reduced need for fatty acid oxidation as energy source in VAR-F48 compared to WT. In the amino acid-related group, proteins that were less abundant in VAR-F48 tended to be involved in biosynthesis pathways, including those for His, Leu, Met, Ile, and Phe. Interestingly, one of the five decreased-DAPs in the nucleotide-related category was annotated as a RelA-SpoT domain-containing protein (B7HPP2), and may be involved in the stringent response (Pulschen et al., 2017). Its low level in VAR-F48 compared to WT (log 2 fold-change $=-3.18$ ) suggests that nutritional status was detected differently by VAR-F48 and WT strains. In the coenzyme-related category, the nine enhanced-DAPs were related to thiamine biosynthesis (B7HWF0, ThiD1 and ThiM), molybdate insertion (B7HPA9, B7HPB0), iron transport (B7HWD6, B7HZS9), and cobalamin synthesis (B7HPB8). The four enhanced-DAPs classed in the defense group, were catalase (KatB), Organic hydroperoxide resistance protein (Ohr), DNA protection during starvation protein 2 (Dps2), and nitric oxide synthase oxygenase (NOS), all of which are involved in the redox/oxidative stress response (Clair et al., 2013; Holden et al., 2013; Shu et al., 2013). Figure 4 (T0) also shows that in carbohydrate, energy, transport, transcription, and pathogenesis-related categories, the numbers 
of enhanced- and decreased-DAPs were almost the same. We examined these categories in detail to detect possible metabolic shifts (Table S2).

(i) In the carbohydrate-related category, enhanced levels of pyruvate formate lyase (Pfl, B7HU44), pyruvate formate lyase activating enzyme (PflA, B7HU45) and alcohol dehydrogenase (Adh, B7HQ62) were associated with decreased levels of TCA enzymes citrate synthase (B7HR26) and isocitrate lyase (B7HZQ5), suggesting that anaerobic catabolic pathways may be induced at the expense of aerobic catabolic pathways in VAR-F48. In addition, enhanced levels of glucose-specific IIABC components of the Phosphotransferase system (PtsG) and glyceraldehyde-3-phosphate dehydrogenase (GapN) may support increasing glycolysis in VAR-F48, and increased expression of lactate utilization proteins A and B (LutA, LutB) may support the use of excreted lactate as carbon source.

(ii) In the energy-related category, four out of seven enhanced-DAPs were components of the respiratory nitrate reductase (NarGHIJ) and two are components of nitrite reductase (NirB, NirD). Among the decreased-DAPs, two were components of the respiratory menaquinonecytochrome $c$ reductase complex (QcrA, QcrC) and two were Etf electron transferring flavoprotein enzymes (EtfA, EtfB). Etfs are known to transfer electrons from a variety of fatty acid or amino acid substrates into the respiratory electron transport chain via an Etf-quinone oxidoreductase and the reduced quinone pool (Garcia Costas et al., 2017). Taken together, these data suggest that the electron transfer process is altered in VAR-F48 compared to WT.

(iii) In the pathogenesis-related group, we noted enhanced expression of NheA and NheB, components of the Nhe enterotoxin, and of the Immune Inhibitor A metalloprotease InhA1. In contrast, the CesA and CesT components of cereulide synthetase were less abundant. This 
profile indicates that the VAR-F48 background favors enterotoxins and InhA1 synthesis at the expense of cereulide in growing cells. Finally, the comparative analysis suggested multiple changes in metabolic pathways that are involved in maintaining redox and energy homeostasis, under stress conditions.

Subgroup T1. The number of DAPs identified only at T1 was $\sim 7$-fold smaller than at T0, indicating a strong down-regulation of both proteomes after $24 \mathrm{~h}$ in groundwater. The majority (21 out 23) of T1-exclusive DAPs were proteins for which expression was enhanced in VARF48. One third of enhanced-DAPs were categorized in amino acid, and translation-related groups (Fig. 4 (T1)), indicating an active metabolism in VAR-F48. Interestingly, the protein with the highest abundance in VAR-F48 compared to WT ( $\log _{2}$ fold-change $=4.6$ ) was the intron-containing RecA protein B7HLB3 (Ko et al., 2002), which was classed in the replication, recombination, and DNA repair COG category. RecA proteins play a central role in DNA stability and repair under stress conditions leading to DNA damage. Taken together, these data suggest that a significant fraction of energy expended by VAR-F48 after $24 \mathrm{~h}$ incubation in groundwater may be used to repair and replace damaged molecules.

Subgroup T2. Of the 68 DAPs identified only at T2, only 15 proteins were detected at higher levels in VAR-F48 compared to WT. These enhanced-DAPs were distributed across 10 functional groups (Fig. 4 (T2)) and include the universal stress protein B7HRR7 and the GTP binding protein Obg (B7HQJ8). Obg acts as an energy sensor to regulate essential cellular processes such as DNA replication and ribosome maturation, and it plays a key role in several stress-adaptation pathways such as the stringent response, and the general stress response (Kint et al., 2014). Obg is also necessary for the stress-induced activation of $\sigma \mathrm{B}$ (Scott and 
Haldenwang, 1999). Although the distribution of enhanced-DAPs within functional groups is relatively homogenous, a high proportion of decreased-DAPs (16) was classed in the sporulation group (SspB, GerQ, GerE, SasP1, B7HQI3, B7HNC6, SpoVFB, SpoIVA, B7HWM2, B7HT37, CotJC, SpoIIID, B7HUB9). This expression pattern suggests that WT actively entered sporulation after $72 \mathrm{~h}$ incubation in groundwater, whereas VAR-F48 underwent starvation and induced a nutrient/energy stress response.

\section{Exoproteome analysis of asporogenic VAR-F48}

We next compared the VAR-F48 and WT exoproteomes after $24 \mathrm{~h}$ (T1) and $72 \mathrm{~h}$ (T2)incubation in groundwater. A total of 160 proteins were identified by at least two peptides (Table S3). Only 13 proteins were found to have differentially accumulated between the strains according to our quantitative and statistical criteria (Table S4). At T1, only two DAPs were identified, both were more abundant in VAR-F48 compared to WT. At T2, 11 DAPs were found, all less abundant in VAR-F48 compared to WT. These DAPs are mainly related to intracellular processes (Table 3), and consequently are not classical secreted proteins (Bendtsen et al., 2005).

\section{Phenotypic characterization of asporogenic VAR-F48}

Since biofilm formation and motility are important for bacterial survival, we tested the ability of VAR-F48 to produce biofilms using a crystal violet assay (Omer et al., 2015). We also tested the capacity of VAR-F48 to engage in swimming and swarming motility (Salvetti et al., 2007). No significant differences in biofilm formation were observed between VAR-F48 
and the parental strain after $24 \mathrm{~h}$ and $48 \mathrm{~h}$ incubation (Fig. 5A). In contrast, biofilm production was higher in VAR-F48 than in WT after $72 \mathrm{~h}(\mathrm{p}<0.05$, according to unpaired two-tailed t-test), at which time WT cells were mainly present as endospores (data not shown). VAR-F48 showed a lower rate of swimming motility than WT (Fig. 5B, $p$-values associated with time, strain and time*strain factors in mixed model were all <0.05), but the two strains showed similar swarming rates (Fig. 5C). In summary, motility but not biofilm production capacity was altered in VAR-F48 compared to WT.

\section{Complementation of the asporogenic VAR-F48 strain}

CtaA is required for cytochrome aa3 oxidase biosynthesis and sporulation in Bacillus subtilis (Mueller and Taber, 1989). Oxidase activity was detectable in both VAR-F48 and WT strains (data not shown). Neither colony morphology nor sporulation were restored following complementation of VAR-F48 with the recombinant replicative plasmid pHT304-ctaA (data not shown). In contrast, VAR-F48 transformed with pHT304-spo0A plasmids formed colonies with similar morphology to wild-type, and sporulated in FNA medium. In addition, deletion of BCAH187_A2382 gene did not impact B. cereus sporulation (data not shown). As compensation of the ctaA mutation did not restore sporulation, and the BCAH187_A2382 gene appeared to play no role in sporulation, these results indicate that the sporulation deficiency in VAR-F48 was due only to the spo0A mutation.

As spo0A regulates the S-layer protein gene sap in B. anthracis (Plaut et al., 2014), we next wished to determine whether spo0A complementation could restore both S-layer protein synthesis and Spo0A synthesis. To do so, we extracted proteins from cellular, medium, and S- 
layer fractions of bacteria for Western blot analysis. The results (Figure 6A) indicated that 100kDa S-layer proteins were absent from VAR-F48 extracts but present in both WT and spo0Acomplemented VAR-F48 samples. Figure 6B shows that synthesis of both Spo0A and the Slayer protein EA1 were restored in spo0A-complemented VAR-F48. Taken together, these results indicate that Spo0A regulates S-layer protein synthesis in B. cereus.

\section{Discussion}

The objective of this study was to determine the survival strategies used by B. cereus in groundwater. Like all other Bacillus species, B. cereus can form dormant endospores to resist adverse conditions. However, this survival strategy is energetically demanding and may only be used when the survival benefits offset the energy cost (Filippidou et al., 2016). Sporulation initiation has been extensively studied in Bacillus subtilis: the key event is the accumulation of the master response regulator Spo0A, under its activated phosphorylated form (Piggot and Hilbert, 2004). Phosphorylation of Spo0A is achieved by a multi-component phosphorelay, orthologs of which were found in species of the B. cereus group, indicating that sporulation initiation could occur in B. cereus by a process similar to that described in B. subtilis.

In this study, we showed that vegetative B. cereus F4810/72 forms endospore when inoculated in oligotrophic groundwater. Formation of endospore followed a period of rapid death that could have triggered sporulation (Liu et al., 2015). However, the endospore population did not persist, and was replaced by an asporogenic mutant population after longterm incubation. Accumulation of asporogenic mutants could result from endospore germination and accumulation of beneficial mutations. Non-persistent asporogenic mutants 
have been described for several Bacillus species, including B. thuringiensis and B. anthracis (Sachidanandham and Jayaraman, 1993; Masel and Maughan, 2007; Maughan et al., 2007; Sastalla and Leppla, 2012). The data presented here show that such asporogenic mutants can accumulate in a natural medium exerting a strong survival pressure. B. cereus ATCC strain 14579 (Fig. S3) did not replicate this asporogenic evolution, indicating that this survival strategy is not common to all B. cereus strains. However, it should be noted that B. cereus F4810/72 and B. cereus ATCC 14579 are completely different genomospecies by literally any possible metric one could use to define "species" (Carroll et al., 2020). In addition, the $B$. cereus. ATCC 14579 type strain and the B. cereus emetic reference strain F4810/72 are classed in different phylogenetic groups (Groups IV and III, respectively (Guinebretiere et al., 2008)). This raises the question of the role of the $B$. cereus genetic background in the emergence of asporogenic mutant populations. This role will be determined by studying a representative number of group III B. cereus s.l. strains.

Genetic analysis of several asporogenic variants of B. cereus F4810/72 isolated from groundwater showed mutations of various types in the gene encoding the pleiotropic response regulator Spo0A. This observation suggested that spo0A mutations may be a direct response to the survival pressure imposed by groundwater in a germination context (Cairns et al., 1988). In VAR-F48, the spo0A mutation was accompanied by mutations in two other genes, which were absent from other variants. This result suggests that these genes are secondary targets of survival pressure, but that mutations may occasionally confer an additional fitness advantage. Comparative proteomics analyses revealed that, unlike WT, VAR-F48 did not synthesize Spo0A, explaining why it fails to sporulate. In addition to not sporulating, VAR-F48 
produced no cereulide biosynthesis proteins or S-layer proteins. Cereulide biosynthesis genes are known to be positively regulated by Spo0A (Ehling-Schulz et al., 2015). Our data also showed that Spo0A positively controls synthesis of the two S-layer proteins, EA1 and the Saplike protein B7HXP4. These two proteins are synthesized at high levels in exponentially growing WT cells (5\% of total Normalized Spectral Abundance Factor in our proteomics data), as reported for other bacteria (Sleytr et al., 2014). Lack of S-layer protein synthesis, S-layer assembly and maintenance at the cell surface constitutes a significant energy saving for VARF48, and other asporogenic cells (Sara and Sleytr, 2000). Beyond sporulation, cereulide and Slayer synthesis, in B. cereus, Spo0A probably regulates several other metabolic processes, like in B. subtilis including overflow metabolism (Tannler et al., 2008).

The results of the comparative proteomics analysis presented here suggest that the VAR-F48 genetic background sustains increased overflow metabolism, both in conditions of carbon excess $\left(\mathrm{MOD}_{50}\right)$ and in oligotrophic conditions. Overflow metabolism refers to a metabolic strategy that favors anaerobic fermentation/respiration pathways over aerobic respiration pathways, even in the presence of oxygen (Basan et al., 2015). Nitrate respiration and several fermentation pathways were up-regulated in growing VAR-F48 cells compared to WT, but only the lactate-producing pathway remained significantly up-regulated in starved cells from groundwater. Overflow metabolism is incompatible with efficient energy production, especially if lactate formation (which produces no ATP) is favored at the expense of aerobic respiration (Szenk et al., 2017). However, it allows rapid growth when carbon and energy are available, as observed for VAR-F48 in MOD50 medium. Rapid catabolism of carbon sources into organic acids is especially advantageous in a natural environment as a strategy to outcompete other 
microorganisms (Silva et al., 2017). In oligotrophic conditions, such as those encountered in groundwater, energy management is a priority for survival, and we can propose various explanations for the maintenance of low energy-efficiency overflow metabolism in VAR-F48. One such explanation is that the biosynthetic cost of the fermentation pathway is lower than that for the electron transport chain (Basan et al., 2015). Alternatively, lack of initiation of sporulation allows VAR-F48 cells to save their remaining energy to adapt to long periods of starvation. Finally, overflow metabolism may be maintained due to carbon catabolite repression (CCR, (Dauner et al., 2001)).

In line with this last hypothesis, we found increased levels of the key regulator of CCR, CcpA, in groundwater cultures. In addition to regulating catabolic pathways, CcpA regulates the expression of virulence factors, especially toxins in B. cereus (van der Voort et al., 2008) and thus limits the energy expenditure required for their synthesis and secretion. Thus, in the absence of Spo0A, CcpA appeared to play an important role in proteome remodeling and orchestration of efficient energy use. Other general contributors to energy utilization and survival in groundwater may be the $\sigma \mathrm{B}$ activating protein, Obg, and the DNA recombination/repair protein RecA proteins. The stringent response inhibits macromolecule synthesis (Dalebroux and Swanson, 2012) and may also play an important role in regulating glycolysis genes (Zhang et al., 2016). In summary, our results indicate that VAR-F48 lacks the Spo0A-dependent sporulation machinery needed to initiate sporulation, but its carefully regulated metabolic status allows it to remain viable in oligotrophic water.

VAR-F48 exhibits a typical GASP-like phenotype (Finkel, 2006), but how VAR-F48 cells find the energy resources needed to survive in groundwater remains open to question. Microscopic 
observations revealed cell lysis in groundwater cultures, suggesting that nutrients to maintain B. cereus cells in an oligotrophic state could be obtained from dead cells.

In conclusion, in this work we showed that sporulation is not the only strategy used by B. cereus to survive in an oligotrophic environment. GASP-like mutants can emerge from $B$. cereus populations and survive in an asporogenic vegetative form. The advantage of vegetative forms over endospores is that vegetative cells can rapidly resume normal growth when nutrient conditions improve, whereas spore germination is time-consuming. Although it does not sporulate and its motility is impaired, VAR-F48 continues to produce biofilm. Biofilm formation could thus be important in contributing to its survival and persistence in a hostile environment.

\section{Experimental procedures}

Groundwater collection and sampling. Groundwater was collected from the superficial aquifer in an agricultural area near Avignon (France), as reported previously (Rousset et al., 2019). Samples were stored in acid-washed, autoclaved 20-L carbon-free polycarbonate Erlenmeyer flasks, and subsequently sterilized by autoclaving $\left(120^{\circ} \mathrm{C}\right.$ for $\left.20 \mathrm{~min}\right)$ before storage at $-20^{\circ} \mathrm{C}$. Calcite was removed from sterile groundwater by filtration at $0.22 \mu \mathrm{m}$ (pore size). The physicochemical parameters of the groundwater were measured before and after treatment, and are shown in Table S5.

Bacterial strains and preculture. Bacillus cereus F4810/72 and its variants were stored at $80{ }^{\circ} \mathrm{C}$ in $30 \%$ glycerol before use. Purity of the stock strains was verified (Shea et al., 2017). 
Cryocultures were streaked onto LB medium and incubated for $72 \mathrm{~h}$ at $16{ }^{\circ} \mathrm{C}$. A single colony was used to inoculate MOD 50 medium, supplemented with $15 \mathrm{mM}$ glucose (Rosenfeld et al., 2005), the initial OD 600 was adjusted to 0.02 , and the culture was incubated at $16^{\circ} \mathrm{C}$ until the OD600 reached 0.07. Cells were then harvested by centrifugation at $10000 \mathrm{x} \mathrm{g}$, for $15 \mathrm{~min}$ at $16^{\circ} \mathrm{C}$. The pellet was washed twice with sterile groundwater, and subsequently used as inoculum.

Culture monitoring and isolation of variants. Aliquots of cultures were removed three times daily, serially diluted, spread onto LB agar plates, plates were supplemented with Congo Red where indicated, and incubated at $30^{\circ} \mathrm{C}$ for $48 \mathrm{~h}$ (Worsham and Sowers, 1999). Plates with 50150 colonies were examined carefully, and colonies that were translucent on LB agar and colorless on Congo Red-containing LB agar, were recorded as variants. Heat-resistant endospores were monitored by counting the cells resistant to a 15 -min heat treatment at $70{ }^{\circ} \mathrm{C}$. Percent of heat-resistant endospores, at one time point was determined as the ratio of the average number of heat-resistant CFUs to the average number of non-heated CFUs. A paired two-tailed t-test was used to determine significance of the difference $(\mathrm{p}<0.05)$ observed between heat-resistant endospore CFUs and non-heated CFU, using XLSTAT software. The Bonferroni method was used to calculate the adjusted $p$-values.

Results were $\log 10$ transformed (Log CFU/mL) and expressed as means \pm standard deviation for each strain from three independent biological replicates. Survival kinetics were modeled for each strain using the biphasic model (Cerf, 1977). The biphasic model parameters (the fraction of the initial population in a major subpopulation (f), and the specific decay rates of the two 
populations) were obtained using the Microsoft Excel ${ }^{\circledR}$ Add-in software, GInaFIT, available at KULeuven/BioTec3 and developed by Geeraerd et al. (2005).

Phenotypic assays. Oxidase activity was determined using oxidase reagent from Biomerieux (France). For sporulation assays, bacteria were grown in Fortified Nutrient Agar (FNA) sporulation medium for $48 \mathrm{~h}$ at $30{ }^{\circ} \mathrm{C}$ after inoculation (OD $\left.600 \mathrm{~nm} \sim 0.002\right)$. Motility and biofilm assays were performed as previously described (Omer et al., 2015). All experiments were run in triplicate. We performed a repeated measures ANOVA test using the mixed models supplied by XLSTAT software to compare motility difference between WT and VAR-F48 strains. A two-tailed t-test was used to evaluate significance of difference observed between WT and VAR-F48 in biofilm assays, using XLSTAT software. The Bonferroni method was used to calculate the adjusted $p$-values.

Proteomics sample preparations. Groundwater medium $(600 \mathrm{~mL}$ in 2-L carbon-free Erlenmeyer flask) was inoculated at an $\mathrm{OD}_{600}$ of 0.02 . Bacteria were grown at $16{ }^{\circ} \mathrm{C}$ with continuous shaking (200 rpm) for approximately 72 h. Samples (200 mL) were collected after 0, 24 and $72 \mathrm{~h}$ incubation. Protein samples from cells and culture supernatants were prepared as previously described (Madeira et al., 2015; Madeira et al., 2016). Briefly, cells were homogenized in NuPAGE® LDS (Lithium dodecyl sulfate) sample buffer 1X (Thermofisher) supplemented with 5\% $\beta$-mercaptoethanol. Homogenates were transferred to 2-ml vials containing silica beads. Samples were pre-treated by heating and ultrasound before producing 
protein extracts by bead-beating in a Precellys Evolution instrument (Bertin Technologies) operated at 10,000 rpm for 10 cycles of $20 \mathrm{~s}$, with $5 \mathrm{~s}$ rest between cycles.

Proteins from culture supernatants were TCA-precipitated, and the resulting pellets were dissolved in NuPAGE buffer.

Protein samples were treated as described elsewhere (Hartmann et al., 2014). Briefly, samples were loaded onto NuPAGE Bis-Tris 4-12\% gels (Invitrogen) for a short 5-min migration at 200 V. Proteins were then digested in-gel with Mass Spectrometry Grade Trypsin Gold (Promega) in the presence of $0.01 \%$ ProteaseMAX surfactant (Promega). Triplicate samples were treated for both WT and VAR-F48 strains.

\section{Protein identification by LC-MS/MS and label free quantification.}

Peptide mixtures resulting from trypsin proteolysis were analyzed on a Q Exactive HF tandem mass spectrometer coupled to an UltiMate 3000 LC system (Dionex-LC Packings) in conditions similar to those previously described (Klein et al., 2016). Briefly, the peptide mixture was first desalted on-line on a reverse-phase precolumn (Acclaim PepMap 100 C18 column; $5 \mu \mathrm{m}$, $100 \AA$, $300 \mu \mathrm{m} \mathrm{id}, \times 5 \mathrm{~mm}$ ), and then resolved at a flow rate of $0.200 \mu \mathrm{L} / \mathrm{min}$ on a reversephase Acclaim PepMap 100 C18 column (3 $\mu \mathrm{m}, 100 \AA$, $75 \mu \mathrm{m}$ id, × 500 mm). Solvent solutions were solvent A ( $0.1 \%$ formic acid) and solvent B ( $0.1 \%$ formic acid and $\left.80 \% \mathrm{CH}_{3} \mathrm{CN}\right)$. For cellular proteins, a 90-min gradient (from 4\% B to 25\% in 75 min followed by an increase to $40 \%$ B) was applied; a 60 -min gradient (from 2.5\% B to 25\% in 50 min followed by an increase to $40 \%$ B) was used for extracellular proteins. The instrument was operated in data-dependent 
mode at a resolution of 60000 to determine the masses of peptides, and applying a Top20 method with a dynamic exclusion of $10 \mathrm{~s}$ to select peptides for fragmentation.

MS/MS spectra were searched using the MASCOT Daemon software version 2.5.1 (Matrix Science) against the B. cereus AH187 NCBI_20180517 database. Parameters included trypsin digestion with a maximum of two missed cleavages, cysteine carbamidomethylation as fixed modification, methionine oxidation as variable modification, and mass tolerance of $5 \mathrm{ppm}$ for peptides and 0.02 Da for MS/MS fragments. Peptide-to-Spectrum Matches were assigned when the $p$-value was below 0.05 in identity threshold mode. Proteins were validated when at least two distinct peptide sequences were assigned to them.

Proteomics data were deposited with the ProteomeXchange consortium (http://proteomecentral.proteomexchange.org) via the PRIDE (Perez-Riverol et al., 2019) partner repository (http://www.ebi.ac.uk/pride/), under dataset identifiers PXD018954 (cellular proteome) and PXD018955 (exoproteome).

Bioinformatics analyses. The $\mathrm{DEP}$ package for $\mathrm{R}$ (https://www.bioconductor.org/packages/release/bioc/html/DEP.html) was used to conduct PCA analysis and determine the significantly differentially accumulated proteins in VAR-F48 compared to WT (Zhang et al., 2018). The DEP package provided functions for data preparation, filtering, variance normalization and imputation of missing values, as well as statistical testing of differentially accumulated proteins (https://www.bioconductor.org/packages/release/bioc/manuals/DEP/man/DEP.pdf). $\quad$ We normalized data using variance stabilizing normalization (vsn). Analysis of protein differential 
accumulation was based on protein-wise linear models and empirical Bayes statistics using limma. A protein was considered differentially accumulated as it exhibited a fold-change $>1.5$ and an adjusted $p$-value $<0.05$ with a false discovery rate $<5 \%$.

Protein functions were assigned using the Clusters of Orthologous Groups (COG) database (Galperin et al., 2015).

The Venn diagram was produced using Venny 2.1.0 software (https://bioinfogp.cnb.csic.es/tools/venny/).

Genomic re-sequencing and PCR analyses. This work has benefited from the facilities and expertise of the high throughput sequencing core facility of I2BC (Centre de Recherche de Gif - http://www.i2bc.paris-saclay.fr/). Genomic DNA of B. cereus F4810 (AH187) WT and F48VAR were isolated using a Genomic DNA isolation kit (Qiagen). Genomic DNA libraries were prepared according to the Nextera DNA library preparation kit (Illumina) protocols. The pooled DNA from each experiment was then subjected to sequencing on an Illumina NextSeq instrument, using a NextSeq 500/550 high output kit v2 (75 cycles, (Illumina) and 75 nucleotide reads. Polymorphisms (SNPs and INDELs) were identified by comparing the B. cereus AH187 (F4810/72) reference genome (GCA_000021225.1), B. cereus F4810/72 WT lab strain and VAR-F48 mutant (Naquin et al., 2014). The data analysis pipeline included bcl2fastq2-2.18.12 (demultiplex, https://emea.support.illumina.com), Cutadapt 1.15 (adapter trimming, https://cutadapt.readthedocs.io/en/v1.15/guide.html), FastQC v0.11.5 (quality control, https://www.bioinformatics.babraham.ac.uk/projects/fastqc/), BWA 0.6.2-r126 (mapping, (Li and Durbin, 2010)), samtools 1.3 (coverage profile, (Li et al., 2009)), VarScan v2.3.9 (variant 
detection, (Koboldt et al., 2012)) and snpEff 4_1b (mutation, (Cingolani et al., 2012)) with default parameters. Sequencing data were deposited in NCBI Biosample data base, via SRA Submission Portal Wizard, under dataset identifiers SAMN15808881, SAMN15808882.

Genomic analysis identified mutations in spo0A, ctaA and BCAH187_A2382, which were confirmed by re-sequencing PCR products.

The sequences of primers used for PCR analysis in this study are listed in Table S6.

Complementation. To complement the spo0A mutation in trans, the 1485-bp locus was first amplified using primer pairs X and Y (Table S6), it was then cloned into pCR-TOPO 2.1. The PCR fragment was cut with BamHI and SacI and ligated to a similarly digested pHT304 vector (Arantes and Lereclus, 1991). For ctaA complementation, the 1477-bp locus was amplified using the primers up-ctaA and down-ctaA (Table S6) and cloned into pCR-TOPO 2.1. The insert was cut with HindIII and SacI and ligated into the pHT304 vector digested with the same enzymes. The integrity of the genes in the recombinant vectors were verified by sequencing. All recombinant vectors were introduced into B. cereus VAR-F48 by electroporation.

Mutant construction. Deletion of BCAH187_A2382 was achieved by allelic replacement, using the temperature-sensitive pMAD (Arnaud et al., 2004). Briefly, 1-kbp flanking DNA sequences upstream and downstream of the BCAH187_A2382 gene were amplified using the appropriate oligonucleotide primers (Table S6). The recombinant PCR products containing DNA sequences upstream and downstream of the BCAH187_A2382 gene were cloned into pCR-TOPO 2.1. The resulting plasmid was digested with SmaI and ligated with a SmaI-digested 
spectinomycin fragment. The EcoRI fragment from the resulting plasmids was cloned into pMAD digested by the same enzyme. The recombinant plasmid was used to transform $B$. cereus F4810/72. The BCAH187_A2382 gene was deleted by a double-crossover event, as previously described (Arnaud et al., 2004). Chromosomal allele exchange was confirmed by PCR with oligonucleotide primers located upstream and downstream of the DNA regions used for allelic exchange.

Cell fractionation and Western blot analysis. Overnight cultures were diluted in LB medium to an $\mathrm{OD}_{600}$ of 0.03 and incubated at $30^{\circ} \mathrm{C}$ until the $\mathrm{OD} 600$ reached 1 . Cultures were centrifuged for $5 \mathrm{~min}$ at $8000 \times \mathrm{g}$ and separated into medium (supernatant) and pellet fractions. Proteins in the medium were precipitated with $10 \%$ (vol/vol) trichloroacetic acid (TCA) for 30 min on ice and centrifuged at $16000 \times g$ for $10 \mathrm{~min}$. Bacterial sediments (pellets) were washed twice with PBS and boiled $\left(100^{\circ} \mathrm{C}\right)$ for $10 \mathrm{~min}$ in $160 \mu \mathrm{L}$ PBS-3 M urea to extract S-layer and S-layerassociated proteins. Extracts were centrifuged at $16000 \times g$, and the S-layer extract was isolated from the bacterial sediment. The S-layer extract was added to an equal volume of sample buffer (4\% SDS, $1 \% \quad \beta$-mercaptoethanol, $10 \%$ glycerol, $50 \mathrm{mM}$ Tris-HCl [pH 7.5], 0.01\% bromophenol blue). The bacterial sediment was washed twice with PBS before mechanical lysis by silica bead-beating for 5 min (FastPrep-24; MP Biomedical). The beads were sedimented to isolate cell lysates. Proteins in the cell lysates were TCA-precipitated and collected by centrifugation at $16000 \times g$ for $10 \mathrm{~min}$. All TCA precipitates were washed with ice-cold acetone and dried. Samples were suspended in $160 \mu \mathrm{L}$ 1-M Tris-HCl (pH 8.0)-4\% SDS and mixed with an equal volume of sample buffer. Aliquots $(15 \mu \mathrm{L})$ of each sample were separated 
on 10\% SDS-PAGE gels and analyzed by Coomassie staining or after transfer to nitrocellulose membranes for immunoblot analysis. Proteins were detected using rabbit antiserum raised against purified EA1 and Spo0A, gifts from Dominique Missiakas (University of Chicago) and Masaya Fujita (University of Houston), respectively. Immunoreactive products were revealed by chemiluminescent detection after incubation with horseradish peroxidase (HRP)-conjugated anti-rabbit antibody.

\section{Acknowledgments}

The authors thank Avignon University foundation for providing financial support for LR's PhD.

\section{Table and Figure legends}

Figure 1. Survival response of B. cereus F4810/72 (WT) in groundwater over a 30-day incubation period at $16{ }^{\circ} \mathrm{C}$. Panel A: CFU counts on LB agar plates. Green trace, total count; black trace, heat-resistant colonies; red trace, colonies with variant morphology. Each value corresponds to the mean of three independent biological replicates \pm SD. The difference between total and heat-resistant count was significant before the first two days and after day 5 (Bonferroni adjusted $p$ value $<0.05$, paired two tailed t-test). The difference between total and variant counts becomes not significant after day 5. Panel B: Colony morphology of WT and variants on LB agar. Panel C: Colony morphology of WT and variants on Congo Redsupplemented LB agar. Arrows indicate morphological variants. 
Figure 2. Survival curves of $B$. cereus VAR-F48 and WT in groundwater over 30 days' incubation at $16{ }^{\circ} \mathrm{C}$. $\log (\mathrm{CFU})$ for WT are indicated with squares, and $\log (\mathrm{CFU})$ for VARF48 are indicated with circles. The three biological replicates are shown for each strain. The red and blue curves represent theoretical data obtained with the biphasic model. The specific rates of decays are $0.54 \pm 0.2$ day $^{-1}$ and $0.14 \pm 0.06$ day $^{-1}$ in the first (day 0 to day 3 ), and the second phase (after day 3), respectively for VAR-F48. The specific rates of decays are $1.47 \pm 0.65$ day $^{-1}$ and $0.04 \pm 0.02$ day $^{-1}$ in the first (day 0 to day 13 ), and the second phase (after day 13), respectively for WT. These values are significantly different in VAR-F48 compared to WT (Bonferroni adjusted $p$ value $\mathrm{p}<0.05$ according to unpaired t-test).

Figure 3. Dynamics of differentially accumulated proteins (DAPs) between VAR-F48 and its parental strain (WT). Panel A: Total protein fraction. PCA was performed to compare the distribution of the three biological replicates at each time-point for both WT and VAR-F48. The axis labels indicate percentage of total variance, which is explained by the first (PC1) and second component (PC2). Panel B: DAPs. Venn diagram shows the number of DAPs at each time-point and the overlaps between time-points. The Venn diagram was drawn with Venny. T0, T1 and T2 correspond to 0, 24 and 72-h incubation time in groundwater.

Figure 4. Clusters of Orthologous Groups (COG) distribution of exclusive DAPs. DAPs were clustered at T0, T1 (24 h) and T2 (72 h). Number of enhanced-DAPs are indicated in red and decreased-DAPs in blue, in each COG group. 
Figure 5. Biofilm development and motility of VAR-F48 and WT B. cereus strains. Panel A. Biofilm formation by VAR-F48 (red) and WT (blue). Biofilm formation was assessed by measuring $\mathrm{OD}_{595 \mathrm{~nm}}$. Data correspond to the mean \pm SD of ten assays. Significant differences are indicated by asterisks (Bonferroni adjusted $p$ value $p<0.05$ in unpaired two-tailed t-test). Panel B. Swimming motility of VAR-F48 (blue) and WT (red). Diameters of motility haloes were measured on TrB plates containing $0.25 \%$ agar. Panel C. Swarming motility of VAR-F48 (blue) and WT (red). Diameters of motility haloes were measured on TrB plates containing $0.7 \%$ agar. Data correspond to the mean \pm SD of triplicate assays.

Figure 6. SDS-PAGE and Western-blot analysis of VAR-F48 and WT protein extracts. Panel A. Coomassie stained SDS PAGE gel. Total protein extracts from the cellular fraction (C), medium fraction (M) and S-layer fraction (S) were separated on 10\% SDS PAGE and stained with Coomassie blue. Panel B. EA1 and Spo0A immuno-detection. Proteins separated on SDSPAGE were transferred onto nitrocellulose membranes for immunoblotting with polyclonal anti-Spo0A and anti-EA1 serum. Protein extracts were prepared from LB cultures of WT, VARF48 and VAR-F48 transformed with the complementing plasmid pHT304-spo0A.

Table 1. Cellular proteins for which differential accumulation was measured between WT and VAR-F48 after $0 \mathrm{~h}, 24 \mathrm{~h}$ and $48 \mathrm{~h}$ incubation in groundwater.

Table 2. Cellular proteins for which differential accumulation was measured between WT and VAR-F48 after both $24 \mathrm{~h}$ and $72 \mathrm{~h}$ incubation in groundwater. 
Table 3: Exoproteins for which differential accumulation was measured in VAR-F48 compared to WT after $24 \mathrm{~h}$ and/or $72 \mathrm{~h}$ incubation in groundwater.

\section{Supplementary data}

Figure S1. DNA sequences and translation of genes identified as mutated in VAR-F48 and other variants isolated from groundwater.

Figure S2. Cultures of $B$. cereus strains in groundwater medium at $16{ }^{\circ} \mathrm{C}$ for proteomics analysis. Panel A: CFU counts for WT colonies, total (blue) and heat-resistant colonies (black). Panel B: CFU counts for VAR-F48 (red). Each value corresponds to the mean of three independent biological replicates \pm SD. T0, T1, and T2 correspond to the sampling times used for the proteomics analysis.

Figure S3. Survival response of B. cereus ATCC 14579 in groundwater over 70 days at $16{ }^{\circ} \mathrm{C}$. Red, total colony count; black, heat-resistant colony count. Values correspond to the mean from three independent biological replicates \pm SD.

Table S1: Proteins identified in the cellular proteomes of F4810/72 (WT) and VAR-F48 strains.

Table S2: Cellular proteins showing differential accumulation between WT and VAR-F48.

Table S3: Proteins identified in exoproteomes from F4810/72 (WT) and VAR-F48 strains.

Table S4: Extracellular proteins showing differential accumulation between WT and VARF48.

Table S5: Physicochemical characteristics of groundwater used to cultivate B. cereus. 
Table S6: Primers used in this study.

\section{References}

Agata, N., Ohta, M., and Yokoyama, K. (2002) Production of Bacillus cereus emetic toxin (cereulide) in various foods. Int J Food Microbiol 73: 23-27.

Arantes, O., and Lereclus, D. (1991) Construction of cloning vectors for Bacillus thuringiensis. Gene 108: 115-119.

Arnaud, M., Chastanet, A., and Debarbouille, M. (2004) New vector for efficient allelic replacement in naturally nontransformable, low-GC-content, gram-positive bacteria. Appl Environ Microbiol 70: 68876891.

Basan, M., Hui, S., Okano, H., Zhang, Z., Shen, Y., Williamson, J.R., and Hwa, T. (2015) Overflow metabolism in Escherichia coli results from efficient proteome allocation. Nature 528: 99-104.

Bendtsen, J.D., Kiemer, L., Fausboll, A., and Brunak, S. (2005) Non-classical protein secretion in bacteria. BMC Microbiol 5: 58.

Brillard, J., Dupont, C.M., Berge, O., Dargaignaratz, C., Oriol-Gagnier, S., Doussan, C. et al. (2015) The Water Cycle, a Potential Source of the Bacterial Pathogen Bacillus cereus. Biomed Res Int 2015: 356928. Cairns, J., Overbaugh, J., and Miller, S. (1988) The origin of mutants. Nature 335: 142-145.

Carlin, F., Brillard, J., Broussolle, V., Clavel, T., Duport, C., Jobin, M. et al. (2010) Adaptation of Bacillus cereus, an ubiquitous worldwide-distributed foodborne pathogen, to a changing environment. Food Research International 43: 1885-1894.

Carroll, L.M., Wiedmann, M., and Kovac, J. (2020) Proposal of a Taxonomic Nomenclature for the Bacillus cereus Group Which Reconciles Genomic Definitions of Bacterial Species with Clinical and Industrial Phenotypes. mBio 11.

Carroll, L.M., Wiedmann, M., Mukherjee, M., Nicholas, D.C., Mingle, L.A., Dumas, N.B. et al. (2019) Characterization of Emetic and Diarrheal Bacillus cereus Strains From a 2016 Foodborne Outbreak Using Whole-Genome Sequencing: Addressing the Microbiological, Epidemiological, and Bioinformatic Challenges. Front Microbiol 10: 144.

Cerf, O. (1977) Tailing of survival curves of bacterial spores. J Appl Bacteriol 42: 1-19.

Cingolani, P., Platts, A., Wang le, L., Coon, M., Nguyen, T., Wang, L. et al. (2012) A program for annotating and predicting the effects of single nucleotide polymorphisms, SnpEff: SNPs in the genome of Drosophila melanogaster strain w1118; iso-2; iso-3. Fly (Austin) 6: 80-92.

Clair, G., Lorphelin, A., Armengaud, J., and Duport, C. (2013) OhrRA functions as a redox-responsive system controlling toxinogenesis in Bacillus cereus. J Proteomics 94: 527-539.

Classen, A.T., Sundqvist, M.K., Henning, J.A., Newman, G.S., Moore, J.A.M., Cregger, M.A. et al. (2015) Direct and indirect effects of climate change on soil microbial and soil microbial-plant interactions: What lies ahead? Ecosphere 6: 1-21.

Dalebroux, Z.D., and Swanson, M.S. (2012) ppGpp: magic beyond RNA polymerase. Nat Rev Microbiol 10: 203-212.

Dauner, M., Storni, T., and Sauer, U. (2001) Bacillus subtilis metabolism and energetics in carbonlimited and excess-carbon chemostat culture. J Bacteriol 183: 7308-7317. 
Dillon, P., Page, D., Vanderzalm, J., Pavelic, P., Toze, S., Bekele, E. et al. (2008) A critical evaluation of combined engineered and aquifer treatment systems in water recycling. Water Sci Technol 57: 753762.

Drobniewski, F.A. (1993) Bacillus cereus and related species. Clin Microbiol Rev 6: 324-338.

Duport, C., Jobin, M., and Schmitt, P. (2016) Adaptation in Bacillus cereus: From Stress to Disease. Front Microbiol 7: 1550.

Duport, C., Zigha, A., Rosenfeld, E., and Schmitt, P. (2006) Control of enterotoxin gene expression in Bacillus cereus F4430/73 involves the redox-sensitive ResDE signal transduction system. J Bacteriol 188: 6640-6651.

Ehling-Schulz, M., Frenzel, E., and Gohar, M. (2015) Food-bacteria interplay: pathometabolism of emetic Bacillus cereus. Front Microbiol 6: 704.

Ehling-Schulz, M., Lereclus, D., and Koehler, T.M. (2019) The Bacillus cereus Group: Bacillus Species with Pathogenic Potential. Microbiol Spectr 7.

Filippidou, S., Wunderlin, T., Junier, T., Jeanneret, N., Dorador, C., Molina, V. et al. (2016) A Combination of Extreme Environmental Conditions Favor the Prevalence of Endospore-Forming Firmicutes. Front Microbiol 7: 1707.

Fimlaid, K.A., and Shen, A. (2015) Diverse mechanisms regulate sporulation sigma factor activity in the Firmicutes. Curr Opin Microbiol 24: 88-95.

Finkel, S.E. (2006) Long-term survival during stationary phase: evolution and the GASP phenotype. Nat Rev Microbiol 4: 113-120.

Galperin, M.Y., Makarova, K.S., Wolf, Y.I., and Koonin, E.V. (2015) Expanded microbial genome coverage and improved protein family annotation in the COG database. Nucleic Acids Res 43: D261269.

Garcia Costas, A.M., Poudel, S., Miller, A.F., Schut, G.J., Ledbetter, R.N., Fixen, K.R. et al. (2017) Defining Electron Bifurcation in the Electron-Transferring Flavoprotein Family. J Bacteriol 199.

Geeraerd, A.H., Valdramidis, V.P., and Van Impe, J.F. (2005) GInaFiT, a freeware tool to assess non-loglinear microbial survivor curves. Int J Food Microbiol 102: 95-105.

Gigliobianco, T., Lakaye, B., Wins, P., El Moualij, B., Zorzi, W., and Bettendorff, L. (2010) Adenosine thiamine triphosphate accumulates in Escherichia coli cells in response to specific conditions of metabolic stress. BMC Microbiol 10: 148.

Gonzalez, I., Lopez, M., Mazas, M., Gonzalez, J., and Bernardo, A. (1995) The effect of recovery conditions on the apparent heat resistance of Bacillus cereus spores. J Appl Bacteriol 78: 548-554.

Gorke, B., and Stulke, J. (2008) Carbon catabolite repression in bacteria: many ways to make the most out of nutrients. Nat Rev Microbiol 6: 613-624.

Green, T.R., and Anapalli, S.S. (2018) Irrigation variability and climate change affect derived distributions of simulated water recharge and nitrate leaching. Water International 43: 829-845.

Guinebretiere, M.H., Velge, P., Couvert, O., Carlin, F., Debuyser, M.L., and Nguyen-The, C. (2010) Ability of Bacillus cereus group strains to cause food poisoning varies according to phylogenetic affiliation (groups I to VII) rather than species affiliation. J Clin Microbio/ 48: 3388-3391.

Guinebretiere, M.H., Thompson, F.L., Sorokin, A., Normand, P., Dawyndt, P., Ehling-Schulz, M. et al. (2008) Ecological diversification in the Bacillus cereus Group. Environ Microbiol 10: 851-865.

Guinebretiere, M.H., Auger, S., Galleron, N., Contzen, M., De Sarrau, B., De Buyser, M.L. et al. (2013) Bacillus cytotoxicus sp. nov. is a novel thermotolerant species of the Bacillus cereus Group occasionally associated with food poisoning. Int J Syst Evol Microbiol 63: 31-40. 
Hartmann, E.M., Allain, F., Gaillard, J.C., Pible, O., and Armengaud, J. (2014) Taking the shortcut for high-throughput shotgun proteomic analysis of bacteria. Methods Mol Biol 1197: 275-285.

Holden, J.K., Li, H., Jing, Q., Kang, S., Richo, J., Silverman, R.B., and Poulos, T.L. (2013) Structural and biological studies on bacterial nitric oxide synthase inhibitors. Proc Natl Acad Sci U S A 110: 1812718131.

Jessberger, N., Krey, V.M., Rademacher, C., Bohm, M.E., Mohr, A.K., Ehling-Schulz, M. et al. (2015) From genome to toxicity: a combinatory approach highlights the complexity of enterotoxin production in Bacillus cereus. Front Microbiol 6: 560.

John, D.E., and Rose, J.B. (2005) Review of factors affecting microbial survival in groundwater. Environ Sci Technol 39: 7345-7356.

Kern, V.J., Kern, J.W., Theriot, J.A., Schneewind, O., and Missiakas, D. (2012) Surface-layer (S-layer) proteins sap and EA1 govern the binding of the S-layer-associated protein BslO at the cell septa of Bacillus anthracis. J Bacteriol 194: 3833-3840.

Kint, C., Verstraeten, N., Hofkens, J., Fauvart, M., and Michiels, J. (2014) Bacterial Obg proteins: GTPases at the nexus of protein and DNA synthesis. Crit Rev Microbiol 40: 207-224.

Klein, G., Mathe, C., Biola-Clier, M., Devineau, S., Drouineau, E., Hatem, E. et al. (2016) RNA-binding proteins are a major target of silica nanoparticles in cell extracts. Nanotoxicology 10: 1555-1564.

Ko, M., Choi, H., and Park, C. (2002) Group I self-splicing intron in the recA gene of Bacillus anthracis. J Bacteriol 184: 3917-3922.

Koboldt, D.C., Zhang, Q., Larson, D.E., Shen, D., McLellan, M.D., Lin, L. et al. (2012) VarScan 2: somatic mutation and copy number alteration discovery in cancer by exome sequencing. Genome Res 22: 568576.

Kolsto, A.B., Tourasse, N.J., and Okstad, O.A. (2009) What sets Bacillus anthracis apart from other Bacillus species? Annu Rev Microbiol 63: 451-476.

Lebeuf-Taylor, E., McCloskey, N., Bailey, S.F., Hinz, A., and Kassen, R. (2019) The distribution of fitness effects among synonymous mutations in a gene under directional selection. Elife 8.

Lever, M.A., Rogers, K.L., Lloyd, K.G., Overmann, J., Schink, B., Thauer, R.K. et al. (2015) Life under extreme energy limitation: a synthesis of laboratory- and field-based investigations. FEMS Microbiol Rev 39: 688-728.

$\mathrm{Li}, \mathrm{H}$. , and Durbin, R. (2010) Fast and accurate long-read alignment with Burrows-Wheeler transform. Bioinformatics 26: 589-595.

Li, H., Handsaker, B., Wysoker, A., Fennell, T., Ruan, J., Homer, N. et al. (2009) The Sequence Alignment/Map format and SAMtools. Bioinformatics 25: 2078-2079.

Liu, Y., Lai, Q., Du, J., and Shao, Z. (2017) Genetic diversity and population structure of the Bacillus cereus group bacteria from diverse marine environments. Sci Rep 7: 689.

Liu, Z., Qiao, K., Tian, L., Zhang, Q., Liu, Z.Y., and Li, F.L. (2015) Spontaneous large-scale autolysis in Clostridium acetobutylicum contributes to generation of more spores. Front Microbiol 6: 950.

Lucking, G., Frenzel, E., Rutschle, A., Marxen, S., Stark, T.D., Hofmann, T. et al. (2015) Ces locus embedded proteins control the non-ribosomal synthesis of the cereulide toxin in emetic Bacillus cereus on multiple levels. Front Microbiol 6: 1101.

Madeira, J.P., Alpha-Bazin, B., Armengaud, J., and Duport, C. (2015) Time dynamics of the Bacillus cereus exoproteome are shaped by cellular oxidation. Front Microbiol 6: 342.

Madeira, J.P., Omer, H., Alpha-Bazin, B., Armengaud, J., and Duport, C. (2016) Deciphering the interactions between the Bacillus cereus linear plasmid, pBClin15, and its host by high-throughput comparative proteomics. J Proteomics 146: 25-33. 
Masel, J., and Maughan, H. (2007) Mutations leading to loss of sporulation ability in Bacillus subtilis are sufficiently frequent to favor genetic canalization. Genetics 175: 453-457.

Maughan, H., Masel, J., Birky, C.W., Jr., and Nicholson, W.L. (2007) The roles of mutation accumulation and selection in loss of sporulation in experimental populations of Bacillus subtilis. Genetics 177: 937948.

Moore, C.M., Nakano, M.M., Wang, T., Ye, R.W., and Helmann, J.D. (2004) Response of Bacillus subtilis to nitric oxide and the nitrosating agent sodium nitroprusside. J Bacteriol 186: 4655-4664.

Mueller, J.P., and Taber, H.W. (1989) Isolation and sequence of ctaA, a gene required for cytochrome aa3 biosynthesis and sporulation in Bacillus subtilis. J Bacteriol 171: 4967-4978.

Naquin, D., d'Aubenton-Carafa, Y., Thermes, C., and Silvain, M. (2014) CIRCUS: a package for Circos display of structural genome variations from paired-end and mate-pair sequencing data. $B M C$ Bioinformatics 15: 198.

Omer, H., Alpha-Bazin, B., Brunet, J.L., Armengaud, J., and Duport, C. (2015) Proteomics identifies Bacillus cereus EntD as a pivotal protein for the production of numerous virulence factors. Front Microbiol 6: 1004.

Perez-Riverol, Y., Csordas, A., Bai, J., Bernal-Llinares, M., Hewapathirana, S., Kundu, D.J. et al. (2019) The PRIDE database and related tools and resources in 2019: improving support for quantification data. Nucleic Acids Res 47: D442-D450.

Pfrunder, S., Grossmann, J., Hunziker, P., Brunisholz, R., Gekenidis, M.T., and Drissner, D. (2016) Bacillus cereus Group-Type Strain-Specific Diagnostic Peptides. J Proteome Res 15: 3098-3107.

Piggot, P.J., and Hilbert, D.W. (2004) Sporulation of Bacillus subtilis. Curr Opin Microbiol 7: 579-586.

Plaut, R.D., Beaber, J.W., Zemansky, J., Kaur, A.P., George, M., Biswas, B. et al. (2014) Genetic evidence for the involvement of the S-layer protein gene sap and the sporulation genes $s p o O A$, spoOB, and spoOF in Phage AP50c infection of Bacillus anthracis. J Bacteriol 196: 1143-1154.

Pulschen, A.A., Sastre, D.E., Machinandiarena, F., Crotta Asis, A., Albanesi, D., de Mendoza, D., and Gueiros-Filho, F.J. (2017) The stringent response plays a key role in Bacillus subtilis survival of fatty acid starvation. Mol Microbiol 103: 698-712.

Ramarao, N., and Sanchis, V. (2013) The pore-forming haemolysins of Bacillus cereus: a review. Toxins (Basel) 5: 1119-1139.

Rosenfeld, E., Duport, C., Zigha, A., and Schmitt, P. (2005) Characterization of aerobic and anaerobic vegetative growth of the food-borne pathogen Bacillus cereus F4430/73 strain. Can J Microbiol 51: 149-158.

Rousset, L., Gillon, M., Duport, C., Clavel, C., Lagree, M., Traika, M. et al. (2019) A first inventory of the labile biochemicals found in Avignon groundwater: can we identify potential bacterial substrates? In $i$ DUST 2018 - Inter-Disciplinary Underground Science \& Technology EDP Sciences.

Sachidanandham, R., and Jayaraman, K. (1993) Formation of spontaneous asporogenic variants of Bacillus thuringiensis subsp. galleriaein continuous cultures. Appl Microbiol Biotechnol 40: 504-507.

Saleem, S., Levison, J., Parker, B., Martin, R., and Persaud, E. (2020) Impacts of Climate Change and Different Crop Rotation Scenarios on Groundwater Nitrate Concentrations in a Sandy Aquifer sustainability 12: 1153.

Salvetti, S., Ghelardi, E., Celandroni, F., Ceragioli, M., Giannessi, F., and Senesi, S. (2007) FlhF, a signal recognition particle-like GTPase, is involved in the regulation of flagellar arrangement, motility behaviour and protein secretion in Bacillus cereus. Microbiology 153: 2541-2552.

Sara, M., and Sleytr, U.B. (2000) S-Layer proteins. J Bacteriol 182: 859-868. 
Sastalla, I., and Leppla, S.H. (2012) Occurrence, recognition, and reversion of spontaneous, sporulation-deficient Bacillus anthracis mutants that arise during laboratory culture. Microbes Infect 14: 387-391.

Scott, J.M., and Haldenwang, W.G. (1999) Obg, an essential GTP binding protein of Bacillus subtilis, is necessary for stress activation of transcription factor sigma(B). J Bacteriol 181: 4653-4660.

Shea, A.A., Bernhards, R.C., Cote, C.K., Chase, C.J., Koehler, J.W., Klimko, C.P. et al. (2017) Two stable variants of Burkholderia pseudomallei strain MSHR5848 express broadly divergent in vitro phenotypes associated with their virulence differences. PLoS One 12: e0171363.

Shu, J.C., Soo, P.C., Chen, J.C., Hsu, S.H., Chen, L.C., Chen, C.Y. et al. (2013) Differential regulation and activity against oxidative stress of Dps proteins in Bacillus cereus. Int J Med Microbiol 303: 662-673.

Siebert, S., Burke, J., Faures, J.M., Frenken, K., Hoogeveen, J., Doll, P., and Portmann, F.T. (2010) Groundwater use for irrigation - a global inventory. Hydrology and Earth System Sciences 14: 18631880.

Silva, I.N., Ramires, M.J., Azevedo, L.A., Guerreiro, A.R., Tavares, A.C., Becker, J.D., and Moreira, L.M. (2017) Regulator LdhR and d-Lactate Dehydrogenase LdhA of Burkholderia multivorans Play Roles in Carbon Overflow and in Planktonic Cellular Aggregate Formation. Appl Environ Microbiol 83.

Sleytr, U.B., Schuster, B., Egelseer, E.M., and Pum, D. (2014) S-layers: principles and applications. FEMS Microbiol Rev 38: 823-864.

Stenfors Arnesen, L.P., Fagerlund, A., and Granum, P.E. (2008) From soil to gut: Bacillus cereus and its food poisoning toxins. FEMS Microbiol Rev 32: 579-606.

Szenk, M., Dill, K.A., and de Graff, A.M.R. (2017) Why Do Fast-Growing Bacteria Enter Overflow Metabolism? Testing the Membrane Real Estate Hypothesis. Cell Syst 5: 95-104.

Tannler, S., Decasper, S., and Sauer, U. (2008) Maintenance metabolism and carbon fluxes in Bacillus species. Microb Cell Fact 7: 19.

van der Voort, M., Kuipers, O.P., Buist, G., de Vos, W.M., and Abee, T. (2008) Assessment of CcpAmediated catabolite control of gene expression in Bacillus cereus ATCC 14579. BMC Microbiol 8: 62.

Worsham, P.L., and Sowers, M.R. (1999) Isolation of an asporogenic (spoOA) protective antigenproducing strain of Bacillus anthracis. Can J Microbiol 45: 1-8.

Zhang, T., Zhu, J., Wei, S., Luo, Q., Li, L., Li, S. et al. (2016) The roles of RelA/(p)ppGpp in glucosestarvation induced adaptive response in the zoonotic Streptococcus suis. Sci Rep 6: 27169.

Zhang, X., Smits, A.H., van Tilburg, G.B., Ovaa, H., Huber, W., and Vermeulen, M. (2018) Proteomewide identification of ubiquitin interactions using UbIA-MS. Nat Protoc 13: 530-550.

Zhou, Y., Zwahlen, F., Wang, Y., and Li, Y. (2010) Impact of climate change on irrigation requirements in terms of groundwater resources. Hydrogeology Journal 18: 1571-1582. 
Table 1. Cellular proteins for which differential accumulation was measured between WT and VAR-F48 after $0 \mathrm{~h}, 24 \mathrm{~h}$ and $48 \mathrm{~h}$ incubation in groundwater.

\begin{tabular}{|c|c|c|c|c|c|c|}
\hline & \multirow{2}{*}{ ORF } & \multirow{2}{*}{ Gene } & \multirow{2}{*}{ Description } & \multicolumn{3}{|c|}{$\log _{2}(\mathrm{FC})^{1}$} \\
\hline & & & & 0 & $24 \mathrm{~h}$ & $72 \mathrm{~h}$ \\
\hline \multicolumn{7}{|l|}{ Decreased in VAR-F48 } \\
\hline \multicolumn{7}{|c|}{ Cell wall/membrane/envelope biogenesis } \\
\hline B7HXP5 & BCAH187_A1065 & eag & S-layer protein EA1 & -7.68 & -7.98 & -7.4 \\
\hline B7HXP4 & BCAH187_A1064 & & Crystal protein & -3.07 & -3.02 & -3.38 \\
\hline B7HYF0 & BCAH187_A5568 & & Putative D-alanyl-D-alanine carboxypeptidase & -1.2 & -2.54 & -2 \\
\hline B7HNA1 & BCAH187_A2059 & & Putative cell wall peptidase & -1.13 & -1.64 & -4.01 \\
\hline \multicolumn{7}{|l|}{ Defense mechanisms } \\
\hline B7HPH5 & BCAH187_A4408 & sodA1 & Superoxide dismutase (EC 1.15.1.1) & -2.06 & -1.74 & -1.77 \\
\hline B7HKH2 & BCAH187_A1610 & hmp & Flavohemoprotein & 1.56 & 2.44 & 3.45 \\
\hline \multicolumn{7}{|l|}{ Unknown function } \\
\hline B7HU83 & BCAH187_A0625 & & AAA_PrkA domain-containing protein & -2.51 & -4.47 & -5.65 \\
\hline \multicolumn{7}{|l|}{ Pathogenesis } \\
\hline Q20CI6 & & cesD & Putative permease & -2.14 & -2.86 & -2.56 \\
\hline A1BYG6 & & $\operatorname{ces} \mathrm{C}$ & $\mathrm{ABC}$ transporter ATP-binding protein & -2.01 & -2.72 & -2.81 \\
\hline \multicolumn{7}{|l|}{ Transcription } \\
\hline B7HNT4 & BCAH187_A4301 & spo0A & Stage 0 sporulation protein $\mathrm{A}$ & -4.61 & -3.82 & -4.02 \\
\hline \multicolumn{7}{|l|}{ Transport } \\
\hline B7HWE1 & BCAH187_A0847 & & Transporter AcrB/AcrD/AcrF family & -3.78 & -3.34 & -3.45 \\
\hline \multicolumn{7}{|l|}{ Enhanced in VAR-F48 } \\
\hline \multicolumn{7}{|c|}{ Carbohydrate transport and metabolism } \\
\hline B7HTY2 & BCAH187_A5012 & ldh & L-lactate dehydrogenase (L-LDH) & 1.81 & 3.64 & 5.12 \\
\hline \multicolumn{7}{|c|}{ Coenzyme transport and metabolism } \\
\hline B7HWF3 & BCAH187_A0885 & thiS & Thiamine biosynthesis protein ThiS & 1.83 & 3.61 & 3.85 \\
\hline \multicolumn{7}{|c|}{ General function prediction only } \\
\hline B7HT11 & BCAH187_A0426 & & $\begin{array}{l}\text { Putative linear gramicidin synthetase } \\
\text { subunit B }\end{array}$ & 1.8 & 3.36 & 3.39 \\
\hline
\end{tabular}

FC: old-change. i.e. NSAF ratio VAR-F48 vs WT

This article is protected by copyright. All rights reserved. 
Table 2. Cellular proteins for which differential accumulation was measured between WT and VARF48 after both $24 \mathrm{~h}$ and $72 \mathrm{~h}$ incubation in groundwater.

\begin{tabular}{|c|c|c|c|c|c|}
\hline \multirow{2}{*}{ Uniprot-ID } & \multirow{2}{*}{ Gene } & \multirow{2}{*}{ ORF } & \multirow{2}{*}{ Description } & \multicolumn{2}{|c|}{$\log _{2}(\mathrm{FC})^{1}$} \\
\hline & & & & $24 \mathrm{~h}$ & $72 \mathrm{~h}$ \\
\hline \multicolumn{6}{|l|}{ Decreased in VAR-F48 } \\
\hline \multicolumn{6}{|c|}{ Lipid transport and metabolism } \\
\hline B7IOM3 & phaC & BCAH187_A1471 & Poly(R)-hydroxyalkanoic acid synthase & -1.92 & -2.08 \\
\hline \multicolumn{6}{|l|}{ Sporulation } \\
\hline B7HLA4 & $\cot E$ & BCAH187_A3817 & Spore coat protein $\mathrm{E}$ & -4.75 & -7.19 \\
\hline \multicolumn{6}{|l|}{ Transcription } \\
\hline B7HM25 & sigE & BCAH187_A3957 & RNA polymerase sigma factor & -4.24 & -4 \\
\hline \multicolumn{6}{|l|}{ Up-DAPs } \\
\hline \multicolumn{6}{|c|}{ Amino acid transport and metabolism } \\
\hline B7HVI1 & hisC & BCAH187_A3002 & Histidinol-phosphate aminotransferase & 2.6 & 2.83 \\
\hline B7I0E7 & $\operatorname{trpE}$ & BCAH187_A1393 & Anthranilate synthase component 1 & 2.97 & 4.2 \\
\hline B7I0F0 & $\operatorname{trpC}$ & BCAH187_A1396 & Indole-3-glycerol phosphate synthase & 3.1 & 2.68 \\
\hline \multicolumn{6}{|c|}{ Cell wall/membrane/envelope biogenesis } \\
\hline B7HPF3 & murG & BCAH187_A4384 & UDP-N-acetylglucosamine & 3.09 & 3.72 \\
\hline B7HZM0 & & BCAH187_A1252 & Putative S-layer protein & 3.25 & 4.29 \\
\hline \multicolumn{6}{|c|}{ Coenzyme transport and metabolism } \\
\hline B7HWF4 & thiG & BCAH187_A0886 & Thiazole synthase & 1.95 & 2.78 \\
\hline B7HT70 & thiE & BCAH187_A0487 & Thiamine-phosphate synthase & 2.66 & 3.5 \\
\hline \multicolumn{6}{|l|}{ Unknown function } \\
\hline B7HK89 & & BCAH187_A1524 & Putative Fumaryl acetoacetate hydrolase & 3.05 & 3.37 \\
\hline B7HYD6 & & BCAH187_A5554 & YwhD family protein & 3.11 & 3.33 \\
\hline \multicolumn{6}{|l|}{ General function predicted } \\
\hline B7HV44 & & BCAH187_A0666 & Putative prophage LambdaBa01 & 1.76 & 1.87 \\
\hline \multicolumn{6}{|c|}{ Signal transduction mechanisms } \\
\hline B7HQ84 & & BCAH187_A2400 & Sensor histidine kinase & 3.36 & 3.26 \\
\hline \multicolumn{6}{|l|}{ Transcription } \\
\hline \multicolumn{6}{|c|}{$\begin{array}{l}\text { Translation. ribosomal structure and } \\
\text { biogenesis }\end{array}$} \\
\hline B7HU81 & & BCAH187 A0623 & Putative tRNA -methyltransferase & 3.57 & 2.78 \\
\hline
\end{tabular}

${ }^{1}$ FC: fold-change. i.e. NSAF ratio VAR-F48 vs WT

This article is protected by copyright. All rights reserved. 
Table 3: Exoproteins for which differential accumulation was measured in VAR-F48 compared to WT after $24 \mathrm{~h}$ and/or $72 \mathrm{~h}$ incubation in groundwater.

\begin{tabular}{|c|c|c|c|c|c|}
\hline \multirow[t]{2}{*}{ Uniprot-ID } & \multirow[t]{2}{*}{ Gene } & \multirow[t]{2}{*}{ ORF } & \multirow[t]{2}{*}{ Description } & \multicolumn{2}{|c|}{$\log _{2}(\mathrm{FC})^{1}$} \\
\hline & & & & $\mathrm{T} 1$ & $\mathrm{~T} 2$ \\
\hline \multicolumn{6}{|c|}{ Carbohydrate transport and metabolism } \\
\hline B7HW93 & tal & BCAH187 A0799 & Probable transaldolase & NS & -4.55 \\
\hline \multicolumn{6}{|c|}{ Coenzyme transport and metabolism } \\
\hline B7HPS6 & $\mathrm{pdxS}$ & BCAH187_A0016 & Pyridoxal 5'-phosphate synthase & 4.08 & NS \\
\hline \multicolumn{6}{|c|}{ Posttranslational modification. protein turnover. chaperones } \\
\hline B7HN40 & & BCAH187_A4193 & Peptidyl-prolyl cis-trans isomerase & 4.80 & NS \\
\hline \multicolumn{6}{|c|}{ Secondary metabolite biosynthesis. transport and catabolism } \\
\hline B7HZW9 & & BCAH187_A3546 & Glyoxalase family protein & NS & -3.77 \\
\hline \multicolumn{6}{|c|}{ Translation. ribosomal structure and biogenesis } \\
\hline B7HQU4 & $\mathrm{rplC}$ & BCAH187_A0141 & 50 S ribosomal protein $\mathrm{L} 3$ & NS & -4.47 \\
\hline B7HQV6 & rplE & BCAH187_A0153 & 50 S ribosomal protein L5 & NS & -4.74 \\
\hline B7HQV9 & $\mathrm{rplF}$ & BCAH187_A0156 & 50S ribosomal protein L6 & NS & -4.47 \\
\hline B7HQV4 & $\mathrm{rplN}$ & BCAH187_A0151 & 50S ribosomal protein L14 & NS & -3.94 \\
\hline B7HLH3 & $\mathrm{rplS}$ & BCAH187_A3887 & 50S ribosomal protein L19 & NS & -6.04 \\
\hline B7HRL2 & rplT & BCAH187_A4697 & 50S ribosomal protein L20 & NS & -5.26 \\
\hline B7HQK2 & $\mathrm{rplU}$ & BCAH187_A4577 & 50S ribosomal protein L21 & NS & -4.49 \\
\hline B7HQU6 & rplW & BCAH187_A0143 & 50S ribosomal protein L23 & NS & -5.79 \\
\hline B7HSJ2 & $\mathrm{rpsD}$ & BCAH187_A4790 & $30 \mathrm{~S}$ ribosomal protein $\mathrm{S} 4$ & NS & -4.24 \\
\hline
\end{tabular}

${ }^{1}$ FC: fold-change. i.e. NSAF ratio VAR-F48 vs WT; NS: Not significant. 

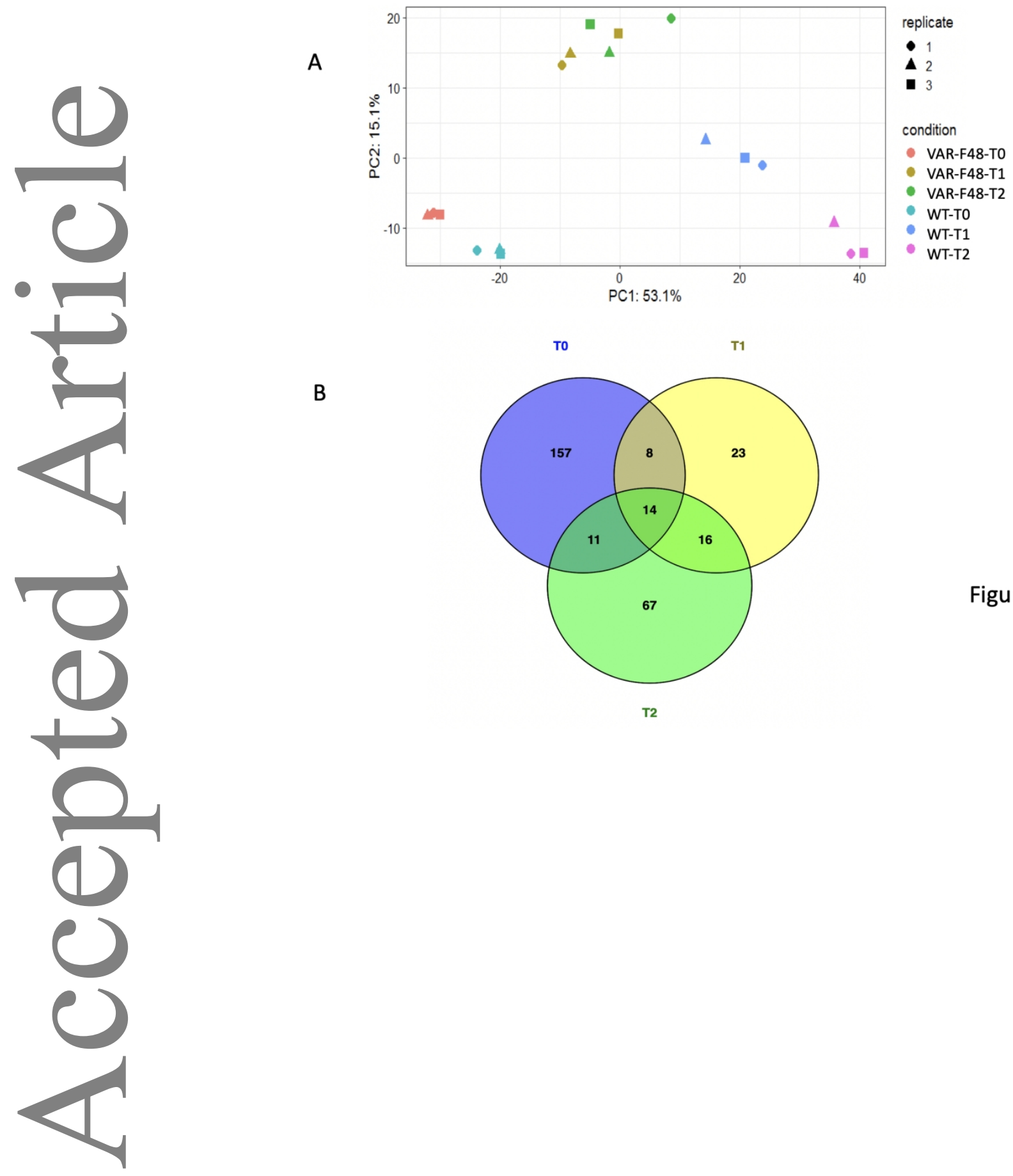

B

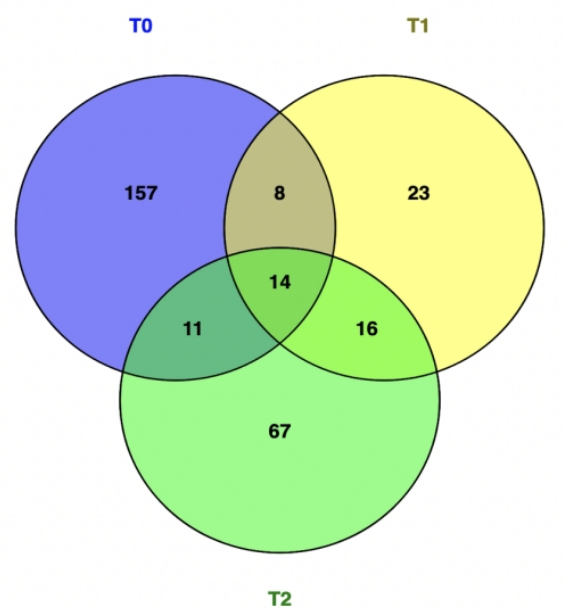

Figure 3

This article is protected by copyright. All rights reserved. 
A

B

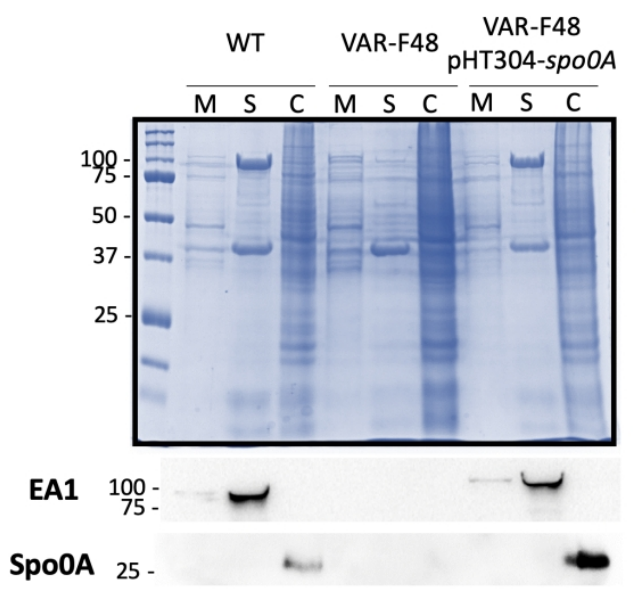

Figure 6

$438 \times 268 \mathrm{~mm}(144 \times 144 \mathrm{DPI})$
Figure 6

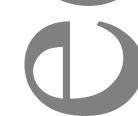

13
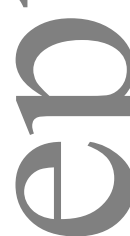

()

()

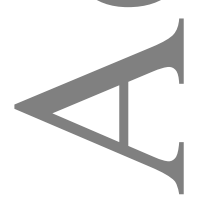

This article is protected by copyright. All rights reserved. 